\title{
Linking Environmental Attitude with Green Purchasing Behavior
}

* Ms. Nitika Sharma

** Dr. C S Sharma

\begin{abstract} https://dx.doi.org/10.33601/effulgence.rdias/v12/i2/2014/42-47

The present study examines the convergence between environmental attitude and green purchasing behavior. The study examines the impact of environmental attitude on General Pro Environmental behavior on one hand and green purchasing intensions on the other. In present we studied the seven variables of environmental attitudes related to respondents' concern for pollution, recycle packaging, switching of products, donation of one day pay and adulterations in products. In this paper a questionnaire is administered with a sample of 171 respondents in Delhi \& NCR, to study the effects of environmental attitude on the green consumers. To examine the questionnaire regression analysis was run and checked $\mathrm{a}=0.05$ significancelevel.
\end{abstract}

E-mail : effulgence@rdias.ac.in, Website : www.rdias.ac.in http://effulgence.rdias.ac.in/user/default.aspX

Key Words: General Pro Environmental, Environmentalattitude, Green Purchasing, Green Consumers

\section{INTRODUCTION}

Grom $\mathrm{CNG}$ vehicle to ban of plastic bags, the 1 concern for environment and environmental consciousness of general public and government in India can be examined. Moreover, Government of India is also rigorously working for environment protection. Recently Ministry of Environment and Forest invested Rs.104 crores in Compensatory Afforestation Fund Management and Planning Authority (CAMPA). Similarly, Social and environment investment has gained a thrust during recent decades in India. Stories of companies like Body shop, MC Donalds and Volvo cited in many business literatures to highlight the importance of environmental marketing. Additionally, green marketing improves corporate image, (D'Souza, Taghian, Lamb \& Peretiatkos 2006) competitive and increase market share (Chan, 2001; Fitzgerald 1993 and Porter)

Despite of environmental consciousness and environmental attitude of general public and government of India, there is an inconsistence in environmental behavior. Exposure to environmental problems does not contribute to environmental behavior and environmental consciousness (Diekmann and Preisendörfer, 1998). Time factor, research complexity, price of a green product, lack of available information on environmental/ social performance of the products/manufactures, cognitive effort in researching restrain consumers to be green. A Cognitive research on green products consumes very much time and effort of consumers. Moreover, higher prices for green products are not being preferred by the consumers. There is also lack of information provided by the marketers on the environmental consequences of the product. It is difficult to predict the consumers' reaction towards green products with a lack degree of accuracy. Likewise, slow development of green products is a result of higher prices or constraints on quality measures for green products (D'Souza, C. Taghian, M and Khosla, R. 2007).

\section{ENVIRONMENTAL CONSCIOUSNESS}

The consumers who exhibit high levels of environmental consciousness make more green purchasing decisions than those exhibiting low levels (Schlegelmilch \& Bohlen, 1996, P 36). The concept of

*Assistant Professor, Rukmini Devi Institute of Advanced Studies, Delhi. (PhD Research Scholar, Punjab Technical University)

** Director, Maharaja Agrasen Institute of Management Studies, Sector- 22, Delhi 
environmental consciousness refers to specific psychological factors related to individuals' propensity to engage in pro-environmental behaviours (Zelezny and Schultz 2000:367). A multi-dimensional and behaviour-oriented definition of environmental consciousness, which in addition to considering different types of pro-environmental behaviors incorporates other factors or psychological constructs that are habitually associated to them: beliefs, values, attitudes, knowledge and others (Jiménez Sánchez, Manuel \& Lafuente, Reginaa, 2010) The domain of "environmental consciousness" is defined as a multidimensional construct, consisting of cognitive, attitudinal and behavioral components (Schlegelmilch \& Bohlen, 1996). Sánchez \& Lafuente, 2010, stated that the operationalization of environmental consciousness includes the four dimensions: affective, cognitive, dispositional and active. Many variables were shown to drive consumer choice in regards to purchasing environmentally friendly products. These variables can be grouped into values, beliefs/knowledge, needs \& motivations, attitudes, and demographics (Bui, 2005).

\section{ENVIRONMENTAL ATTITUDE}

Psychologists define an attitude as an enduring evaluation, positive or negative, of people, objects, or ideas. (Eagly and Chaiken, 1998). A person's overall evaluation of persons (including oneself), objects, and issues consider to be an attitude (Petty \& Wegener, 1998). Environmental attitudes are defined as an individual's concern for the physical environment. In regards to the effects of environmental attitudes on behavior, findings suggest that attitudes are the most consistent predictor of pro-environmental purchasing behaviors (Schlegelmilch, Greg, and Diamantopoulos 1996). Environmental attitudes are commonly perceived as preconditions for achieving environmental behavior ( Eilam \& Trop , 2012). (2001) stated that attitude impact on the willingness of consumers to spend more for environmentally friendly products.

\section{STUDY OBJECTIVES}

The objectives of present study are:

1. To study different aspects of environmental attitude

2. To identify the effects of environmental attitude on green purchasing behavior.

\section{Method}

The study is based on analysis of data collected from business executives through questionnaire / instruments, using regression analysis.

\section{Sample}

The sample consisted of 171 business executives in the age group of $28-50$ years. $40 \%$ of the respondents were in the age group of $28-35$ years. $32 \%$ in 35- 40 years and rest belong to age group between 40 - 46 years. The respondents were residents of Delhi \& National Capital Region (NCR). Gender wise distribution of the sample showed that $32 \%$ were females and $68 \%$ were males. 30\% respondents were graduates and rest were PG or above.

\section{INSTRUMENT}

Kollmuss and Agyeman (2002) and Jensen (2002) define pro-environmental behavior as conscious actions taken by an individual so as to minimize the negative impact of human activities on the environment or to improve the environment. For example, while purchasing a CFL bulb or buying jute bag over plastic bags shows "pro- environmental behavior". Hence for operationalization of the concept general pro environmental behavior has been considered as dependent variable in this study. In literature review of General Pro Environmental behavior we captured general purchasing scale of Schlegelmilch, Greg, and Diamantopoulos. 1996 which included three green purchasing statements as per Annexure- I. the individual items were in Likert format with five scales stating "Always true" to "Never True".

The Ecological attitudes and Knowledge Scale (EAKS) have proven criterion validity and high reliability. The original true/false and multiple-choice question formats of the EAKS were, however, replaced by interval scales. To reduce the burden on respondents, the scale was shortened to a 7-item Likert scale. An attitude scale containing of seven items scales directed at respondent's concern about environment developed by Maloney \& Ward, 1975. As per table -I each respondents rated each of the items from 1 (Strongly Agree) to 5 (strongly disagree) in response to the question. 


\section{ANALYSIS AND DISCUSSION}

Indian consumers are becoming cognizant with respect to green purchasing (Sharma \& Sharma, 2013). The self-consciousness in respect of green purchase among consumers is increasing. When respondents were asked, whether they tried to discover about the effects of products on environment , $81 \%$ of the respondents stated that they tried to discover the impact of product on environment from always to sometimes.

Most respondent stated, they will choose green product or environmentally - friendly alternative if one of similar prices was available. This indicates that consumers are ready to buy green products. Marketers need plan and add efforts to encourage their green purchasing. This study revealed that $97 \%$ of the respondent would have purchased green product with no difference in the prices.

However, price of ecofriendly product may cause negative green purchasing behavior among the Indian customers. Hence it is very important for an organization not to keep prices of its green product high (Sharma \& Sharma, 2013). As in the study only $60 \%$ of the respondents were agreed to purchase green products regardless of the prices, whereas $40 \%$ would never purchase green products at higher prices.

Table- I Regression Analysis showing impact of GPB with variables of Environmental Attitude

\begin{tabular}{|c|c|c|c|c|c|c|c|}
\hline \multicolumn{8}{|c|}{ DEPENDENT VARIABLE- GPB } \\
\hline & Model 1 & Model 2 & Model 3 & Model 4 & Model 5 & Model 6 & Model 7 \\
\hline Variable 1 & $\begin{array}{l}0.546 * \\
(0.222)\end{array}$ & $\begin{array}{l}0.543^{*} \\
(0.222)\end{array}$ & $\begin{array}{l}0.482^{*} \\
(0.222)\end{array}$ & $\begin{array}{l}0.456^{*} \\
(0.21)\end{array}$ & $\begin{array}{l}0.403 \\
(0.212)\end{array}$ & $\begin{array}{l}0.304 \\
(0.188)\end{array}$ & $\begin{array}{l}0.298 \\
(0.189)\end{array}$ \\
\hline Variable 2 & & $\begin{array}{l}0.078 \\
(0.202)\end{array}$ & $\begin{array}{l}0.091 \\
(0.198)\end{array}$ & $\begin{array}{l}0.042 \\
(0.189)\end{array}$ & $\begin{array}{l}0.028 \\
(0.188)\end{array}$ & $\begin{array}{l}0.015 \\
(0.165)\end{array}$ & $\begin{array}{l}-0.053 \\
(0.181)\end{array}$ \\
\hline Variable 3 & & & $\begin{array}{l}0.318 \\
(0.189)\end{array}$ & $\begin{array}{l}0.152 \\
(0.190)\end{array}$ & $\begin{array}{l}0.162 \\
(0.189)\end{array}$ & $\begin{array}{l}0.080 \\
(0.167)\end{array}$ & $\begin{array}{l}0.125 \\
(0.175)\end{array}$ \\
\hline Variable 4 & & & & $\begin{array}{l}0.6275^{*} \\
(0.237)\end{array}$ & $\begin{array}{l}0.560^{*} \\
(0.240)\end{array}$ & $\begin{array}{l}0.300 \\
(0.222)\end{array}$ & $\begin{array}{l}0.245 \\
(0.230)\end{array}$ \\
\hline Variable 5 & & & & & $\begin{array}{l}-0.242 \\
(0.176)\end{array}$ & $\begin{array}{l}-0.009 \\
(0.166)\end{array}$ & $\begin{array}{l}-0.044 \\
(0.170)\end{array}$ \\
\hline Variable 6 & & & & & & $\begin{array}{l}0.768^{*} \\
(0.194)\end{array}$ & $\begin{array}{l}0.771^{*} \\
(0.194)\end{array}$ \\
\hline Variable 7 & & & & & & & $\begin{array}{l}0.162 \\
(0.175)\end{array}$ \\
\hline $\mathbf{R}^{2}$ & 0.1001 & 0.1026 & 0.1478 & 0.2485 & 0.2758 & 0.4481 & 0.4575 \\
\hline
\end{tabular}

$*(p<0.05)$

Table I the study examined the impact of General Pro Environmental behavior with variables of environmental attitude. Regression was run to examine whether different aspects of environmental attitude affect General Pro Environmental Behavior. Model 1 shows that there is significant relationship between GPB and willingness of respondents to take bus or metro to reduce air pollution $(\mathrm{P}<0.05)$. It reflects the explanatory of environmental attitude on green buying behavior. Model 2 uses two variables namely willingness of respondents to take bus or metro to reduce air pollution and respondents not concern for environment as it is government's job. .In model 2, $\mathrm{R}^{2}$ does not change much in comparison of model 1 while, willingness of respondents to take bus or metro emerges significant. It implies: one, respondents are concerned about environment. Two, respondents who want to reduce pollution are keen to buy green products. Three, respondents comprehend that it's not solely Government's job to take care about the environment but also of each individual. Four, it reflects that respondents taking responsibility of environment shows green purchasing 
intentions. In model 3, only willingness to reduce pollution is significant with GPB $(\mathrm{P}<0.05)$ and donating a day pay to improve environment is insignificant $(\mathrm{P}>0.05)$. It implies that respondents are not ready to spend their one day compensation for improvement of environment. In past literature it has been observed that people are not very much willing to spend their household income for the improvement of environment (Ready, Malzubris and Senkane, 2002).

In model 4, there is a substantial increase in $\mathrm{R}^{2}$ as compare to model 3, prima facie, greater relevance of model 4 relative to model 3 . In model 4 , it has been observed that respondents are willing to stop buying products from companies guilty of polluting the environment, even though it might be convenient. It implies that respondents are prepared to switch products for ecological reasons and stop buying products from companies that cause pollution (Fraj and Martinez, 2007). In model 5, there is more or less same $\mathrm{R}^{2}$ as of model 4 . It has been observed that variable 4 is significant to GPB and variable 5 is insignificant $(\mathrm{P}>0.05)$. It has been observed that variable 5 has negative coefficients which reflect that respondents try to make special efforts in buying products in recyclable containers. In past studies it have been investigated that consumers prefer to buy recycled packed products (Bei, LienTi; Simpson, Eithel M., 1995). There is a significant increase in $\mathrm{R}^{2}$ of model 6 relative to model 5. It shows that greater relevance of respondents' willingness to switch products for ecological motives. In earlier literature it has been revealed that consumers buy products that are environmental beneficial or switch products for environmental reasons ( Mainieri, Barnett, Valdero, Unipan \& Oskamp, 1997). In model $7, \mathrm{R}^{2}$ does not change much which indicates that variable 7 has no impact on GPB. Moreover, it has been observed that variable 7 is insignificant with GPB. Simply claiming "green" is no longer enough to motivate consumers to choose green products (Straughan \& Roberts, 1999), proving the struggle to preserve the environment motivates green buying behavior.

Table- II Likelihood test of GPB with variables of Environmental Attitude

\begin{tabular}{|l|l|c|c|}
\hline Tests of Model Effects & \\
\hline Source & Type III & Df & Sig. \\
\hline (GPB) & Likelihood Ratio Chi-Square & 1 & .000 \\
Variable 1 & 142.649 & 1 & .093 \\
Variable 2 & 2.820 & 1 & .753 \\
Variable 3 & .099 & 1 & .443 \\
Variable 4 & .588 & 1 & .254 \\
Variable 5 & 1.301 & 1 & .782 \\
Variable 6 & .077 & 1 & .000 \\
Variable 7 & .979 & 1 & .322 \\
\hline
\end{tabular}

Dependent Variable: VAR00001

Model: (Intercept), VAR00002, VAR00003, VAR00004, VAR00005, VAR00006, VAR00007, VAR00008

In table - II, as per likelihood ratio test only variable 6 (I have switched products for ecological reasons) adds to the predictive/ power of the model.

\section{LIMITATIONS AND DIRECTION FOR FUTURE RESEARCH}

The study is not free from limitations. First sample size is small; therefore it is difficult to generalize the finding. Secondly, the study is exploratory in nature and is based on sample confined to Delhi and NCR. There is a need to examine the subject over a sample extending to other states of the country. Thirdly, in this paper for dependent variable general pro environmental behavior is considered, for better consistency and future research actual pro environmental purchasing behavior can be investigated. Fourth, for future investigation 
research can scrutinize more environmental factors that may motivate consumers' green purchasing behavior.

\section{REFERENCE}

1. Bei, Lien-Ti; Simpson, Eithel M., (1995), "The Determinants of Consumers' Purchase Decisions for Recycled Products: An Application of Acquisition-Transaction Utility Theory", Advances in Consumer Research, Vol. 22 Issue 1, p257-261. $5 \mathrm{p}$.

2. Chase, D., Smith, T.K. (1992), "Consumers keen on green but marketers don't deliver",Advertising Age, June, pp.63.

3. Diekmann. A \& Preisendörfer. P. (1998) "ENVIRONMENTAL BEHAVIOR DISCREPANCIES BETWEEN ASPIRATIONS AND REALITY", Rationality and Society February 1998 vol. 10 no. 1 79-102

4. D'Souza, C. Taghian, M and Khosla, R. (2007), "Examination of environmental beliefs and its impact on the influence of price, quality and demographic characteristics with respect to green purchase intention", Journal of Targeting, Measurement and Analysis for Marketing (2007) 15, 69-78

5. D'Souza. C, Taghian. M, Lamb.R \& Peretiatkos.P. (2006), "Green products and corporate strategy: an empirical investigation", Society and business review, vol. 1, no. 2, pp. 144-157.

6. Fraj. E and Martinez. E (2007), "Ecological consumer behaviour: an empirical analysis", International Journal of Consumer Studies, Volume 31, Issue 1, pages 26-33, January 2007.

7. Fitzgerald, K. (1993), "It's green, it's friendly, it's wal mart, eco store", Advertising Age, Vol.1 pp.44.

8. Geller, E.S. (1989). Applied behavior analysis and social marketing: An integration for environmental preservation. Journal of Social Issues, 45,17-36.

9. Jensen, B.B. (2002). Knowledge, action and proenvironmental behaviour. Environmental Educational Research, 8(3), 325-334.

10. Kollmuss, A. and J. Agyeman (2002). Mind the Gap: Why do people act environmentally and what are the barriers to pro-environmental behavior?. Environmental Education Research, 8(3), 239-260.

11. Ken Peattie, Andrew Crane, (2005) "Green marketing: legend, myth, farce or prophesy?",
Qualitative Market Research: An International Journal, Vol. 8 Iss: 4, pp.357 - 370.

12. Petty, R.E.; Wegener, D.T. Attitude Change: Multiple Roles for Persuasion Variables. In The Handbook of Social Psychology, 4th ed.; Gilbert, D., Fiske, S., Lindzey, G., Eds.; McGraw-Hill: New York, NY, USA, 1998; pp. 323-389.

13. Porter, M., Van der Linde, C. (1995a), "Green and competitive: ending the stalemate", Harvard Business Review, Vol. 73 No.5, pp.120 34.

14. Mainieri. T, Barnett E.G, Valdero T.R, Unipan. J.B \& Oskamp. S , (1997), "Green Buying: The Influence of Environmental Concern on Consumer Behavior", The Journal of Social Psychology, Vol. 137, Iss. 2, 1997.

15. Maloney, M.P.,Ward,M.P. \& Braucht, G.N.(1975) Psychology in action : a revised scale for the measurement of ecological attitudes and knowledge.

American Psychologies,Vol.30,p.787-790

16. McDaniel, S.W. and Rylander, D.H. (1993), "Strategic green marketing", The Journal of Consumer Marketing, Vol. 10 No. 3, pp. 4-11.

17. Richard C. Ready, Jânis Malzubris and Silva Senkane (2002), "The relationship between environmental values and income in a transition economy: surface water quality in Latvia”, Environment and Development Economics, Volume Issue 01, pp 147-156.

18. S. Bamberg, G. Mo"ser (2007), "Twenty years after Hines, Hungerford, and Tomera: A new meta-analysis of psycho-social determinants of pro-environmental behavior" , Journal of Environmental Psychology, Volume 27, Issue 1, March 2007, Pages 14-25.

19. Schlegelmilch, Bodo B., Greg M. Bohlen. and Diamantopoulos, Adamantios. (1996), "The link between green purchasing decisions and measures of environmental consciousness", European Journal of Marketing, Vol. 30 No. 5, 1996, pp. 35-55.

20. Schwartz, J. (1990), "Earth day today", American Demographics, Vol. 12 No. 4, pp. 401.

21. Sharma. N and Sharma. C.S (2013), “ Encouraging green purchasing behavior through green branding", Business Analyst, Vol. 34 No.2, pp. 65-76.

22. Simon, F.L. (1992), "Marketing green products 
in the triad", The Columbia Journal of World Business, Vol. 27 Nos 3-4, pp. 268-85.

23. Stern, P.C. (1999), "Information, incentives, and pro-environmental consumer behaviour", Journal of Consumer Policy, Vol. 22 No. 4, pp. 461-78.

24. Straughan, Robert D. and Roberts James A. (1999), "Environmental segmentation alternatives: a look at green consumer behavior in the new millennium", JOURNAL OF CONSUMER MARKETING, VOL. 16 NO. 6 1999, pp. 558-575.
25. Zelezny, L.C. and P.W. Schultz. 2000. "Promoting Environmentalism." Journal of Social Issues, 56:365371.

\section{Annexure- I}

\section{Summary of Issues of Environmental Attitude}

\begin{tabular}{|c|c|}
\hline Variable 1 & I'd be willing to ride a bicycle or take the bus to work in order to reduce air pollution. \\
\hline Variable 2 & $\begin{array}{l}\text { I'm really not willing to go out of my way to do much about ecology since it's the } \\
\text { government's job }\end{array}$ \\
\hline Variable 3 & I would donate a day's pay to a foundation to help improve the environment \\
\hline Variable 4 & $\begin{array}{l}\text { I would be willing to stop buying products from companies guilty of polluting the } \\
\text { environment, even though it might be convenient }\end{array}$ \\
\hline Variable 5 & I don't make a special effort to buy products in recyclable containers \\
\hline Variable 6 & I have switched products for ecological reasons. \\
\hline Variable 7 & I feel people worry too much about pesticides on food products. \\
\hline
\end{tabular}

